\title{
GRASS RHIZOSHEATHS: ASSOCIATED BACTERIAL COMMUNITIES AND POTENTIAL FOR NITROGEN FIXATION
}

\author{
David Bergmann ${ }^{1}$, Mike Zehfus², Linda Zierer ${ }^{1,3}$, Brian Smith¹, and Mark Gabel ${ }^{1,4}$
}

\begin{abstract}
Rhizosheaths are structures composed of mucilage secreted from plants and adherent soil particles that form a cylinder around the root. Using scanning electron microscopy (SEM), we observed bacteria associated with rhizosheaths of the grasses Achnatherum hymenoides, Calamovilfa longifolia, Hesperostipa comata, and Pascopyrum smithii from a sand dune area in Harding County in northwestern South Dakota. The greatest numbers of bacteria, observed with SEM $\left(529 \mathrm{~mm}^{-2}\right)$, and the greatest number of culturable bacteria $\left(9.9 \times 10^{7} \mathrm{CFU} \cdot \mathrm{g}^{-1}\right.$ or $\left.5178 \mathrm{CFU} \cdot \mathrm{mm}^{-2}\right)$ were on rhizosheaths of $C$. longifolia. Rhizosheaths of all the grasses examined contained a higher density of bacteria than the surrounding soil. Nitrogen fixation, as assayed by reduction of acetylene to ethylene, was present in some rhizosheaths. Bacterial nifH gene sequences amplified from bacteria associated with rhizosheaths were most similar to those from Alcaligenes latus and Mesorhizobium loti.
\end{abstract}

Key words: rhizosheath, nitrogen fixation, bacteria, Poaceae, nifH.

Grasses (Poaceae) include about 10,000 species and inhabit many varied habitats (Campbell 1985). About 70\% of cultivated land is planted in crop grasses (Judd et al. 1999). Most grasses are not hosts to nitrogen-fixing bacteria, and growth of grasses may be inhibited due to a deficiency of nitrogen (Hopkins 2000). Grasses growing on relatively nutrientpoor soils are at a particular disadvantage, and growth may be greatly enhanced by soil bacteria (Kuske et al. 2002).

Although dinitrogen gas $\left(\mathrm{N}_{2}\right)$ comprises $78 \%$ of earth's atmosphere, nitrogen is often limiting for organisms in many terrestrial ecosystems because plants and animals cannot utilize dinitrogen directly as a nitrogen source. During nitrogen fixation, dinitrogen gas is reduced to ammonia $\left(\mathrm{NH}_{3}\right)$, making nitrogen available for uptake by various organisms. Microbial nitrogen fixation accounts for $53.8 \%$ of terrestrial nitrogen fixation, which is greater than anthropogenic nitrogen fixation due to ammonia fertilizer production $(38.5 \%)$ and abiotic $(7.7 \%)$ nitrogen fixation (Schlesinger 1991). Diverse groups of Bacteria and some Archaea fix nitrogen, including many free-living soil bacteria and plant-associated symbionts such as the Rhizobiaceae, which inhabit the root nodules of legumes.

Microbial nitrogen fixation is catalyzed by the nitrogenase enzyme complex, which con- sists of a 2-subunit dinitrogenase component, encoded by the genes nif $\mathrm{D}$ and nif $\mathrm{K}$, and a dinitrogenase reductase subunit, encoded by the nifH gene (Wang et al. 1988, Madigan and Martinko 2006). This nitrogenase complex also reduces acetylene to ethylene. Hence, the potential for nitrogen fixation may be assayed by incubating an anaerobic sample with acetylene and analyzing the sample for conversion of acetylene to ethylene (Knowles and O’Toole 1975, Turner and Gibson 1980, Boddey 1987, Capone 1993, Weaver and Danso 1994).

Some species of grasses possess rhizosheaths (Wullstein et al. 1979, Wullstein 1980, Buckley 1982). The rhizosheath consists of a layer of sand grains tightly bound to the root by mucilage, a mucopolysaccharide. The function of rhizosheaths in grasses is not well understood. Price (1911) suggested that the rhizosheath is important in water conservation, and this idea was supported by Young (1995), who stated that mucigel within the rhizosheath increases water-holding capacity. Other suggestions of rhizosheath function include harboring bacteria that fix nitrogen, thereby supplying the plant with ammonia in soils where nitrogen is limiting (Wullstein et al. 1979, Wullstein 1980, Buckley 1982).

The rhizosphere, or region of soil adjacent to a plant root, has been reported to have higher overall numbers of bacteria as well as

\footnotetext{
${ }^{1}$ Department of Biology, Black Hills State University, 1200 University, Spearfish, SD 57799

${ }^{2}$ Department of Chemistry, Black Hills State University, 1200 University, Spearfish, SD 57799.

${ }^{3}$ Deceased

${ }^{4}$ Corresponding author. E-mail: markgabel@bhsu.edu
} 
differences in the composition of bacterial species when compared to the bulk soil surrounding it (van Diepeningen et al. 2005). Gochnauer et al. (1989) determined bacterial numbers associated with rhizosheaths of maize. They reported similar numbers of viable bacteria in bare root regions and in roots with rhizosheaths, but they isolated more spore-forming bacteria and bacteria capable of growth in nitrogen-free media from sheathed regions. Evidence for nitrogen fixation in soil has been measured using an acetylene reduction assay (Turner and Gibson 1980). Andrews et al. (2003) reviewed nitrogen fixation in cultivated grasses and noted that few bacteria-grass interactions have been studied and those that have been studied have produced inconsistent levels of usable nitrogen.

The difficulty of studying organisms in the rhizosphere has been noted by Hawkes et al. (2007). Most work with rhizosphere microbes has been done on their relationships with agronomically important plant species (Hawkes et al. 2007). One recent study reported microbe-root interaction on 3 grass species in an arid grassland of Utah (Kuske et al. 2002). Bacterial communities in the soil are essential for biogeochemical cycling of elements such as carbon and nitrogen, especially in aridlands (Kuske et al. 2002). The study of bacterial communities in the rhizosphere of plants is complicated by the fact that perhaps $90 \%$ of the bacterial species present in the soil are not readily culturable using standard bacteriological techniques (Ward et al. 1990). Despite the pitfalls of culture-based techniques, the composition and diversity of soil (and rhizosphere) microbial communities may be examined by extraction of total microbial DNA and PCR of selected genes.

The purpose of this study was to determine the abundance of bacterial communities on the rhizosheaths of grasses growing in sand dune environments. We hypothesized that there would be more bacteria in the root/rhizosheath complex than in the surrounding bulk soil. Secondarily, we hypothesized that at least some of the bacteria associated with the root/rhizosheath complex would be capable of nitrogen fixation.

\section{Methods}

\section{Study Site}

The study site $\left(45^{\circ} 33.4^{\prime} \mathrm{N}, 103^{\circ} 29.6^{\prime} \mathrm{W}\right)$ is located in an area with a continental climate with large seasonal and daily temperature fluctuations. Elevation at the site is approximately $900 \mathrm{~m}$. The nearest weather-reporting station (approximately $15 \mathrm{~km}$ ESE) recorded an average annual precipitation of $37.6 \mathrm{~cm}$, with the greatest amount of rain in June $(7.6 \mathrm{~cm})$. Temperature extremes recorded from 1993 to 2005 ranged from $42{ }^{\circ} \mathrm{C}$ in July to $-39{ }^{\circ} \mathrm{C}$ in January. The average wind velocity was 19.0 $\mathrm{km} \cdot \mathrm{h}^{-1}$ (South Dakota Office of Climatology 2006). The soil present at the study site is characterized as Zeona loamy fine sand. Organic or mineral horizons were not observed in the active dunes. In flat areas the sand is approximately $150 \mathrm{~cm}$ deep, while some dunes are greater than $6 \mathrm{~m}$ in height (Johnson 1988). Vegetation across the region is a mixed grassland, with dominant plants on the dune tops including Calamovilfa longifolia (Hook.) Scribn., Achnatherum hymenoides (R. \& S.) Barkw., Psoralidium lanceolatum (Pursh) Rydb., and Rumex venosus Pursh.

\section{Field Sampling}

Two transects of $100 \times 2 \mathrm{~m}$ were established longitudinally along 2 dune tops in a sand dune area in Harding County in northwestern South Dakota. Due to the prevailing northwest winds, dunes (and thus, transects) run in a northwest to southeast direction. Plant specimens were obtained 7 June 2006. Entire plants were collected to ensure that the roots being studied were properly identified. The plants collected for this study were $A$. hymenoides (R. \& S.) Barkw., C. longifolia (Hook.) Scribn., Hesperostipa comata (Trin. \& Rupr.) Barkw., and Pascopyrum smithii (Rydb.) A. Löve. Due to the sparse vegetation on the dune tops, percent cover was not measured. For enumeration of bacteria by scanning electron microscopy (SEM) and by culturing, rhizosheaths of 6 plants of each species as well as ten 20-g samples of bulk soil were collected. Bulk soil samples used for determination of soil bacteria were collected from approximately $5-10 \mathrm{~cm}$ below the surface of the dune tops at least $1 \mathrm{~m}$ away from the nearest visible plant stem.

Fourteen samples were collected from each transect for soil analysis, 7 at $0-15 \mathrm{~cm}$ and 7 at $15-46 \mathrm{~cm}$. Samples from each transect were pooled for determination of percent organic matter (determined by weight loss upon ignition) and nitrate (determined from $0.01 \mathrm{M}$ 
$\mathrm{Al}_{2}\left(\mathrm{SO}_{4}\right)_{3} 0.02 \mathrm{M} \mathrm{H}_{3} \mathrm{BO}_{3}$ ), phosphorus (determined by $0.5 \mathrm{M} \mathrm{NaHCO}$ ), and potassium concentrations (determined by $1 \mathrm{~N} \mathrm{NH}_{4} \mathrm{OAc}$ ) by the Soil Laboratory at South Dakota State University. Soil particle surface area was estimated by 2 methods to allow comparisons of our analysis to published values of bacterial abundance. Soil particles in 2 samples of sand were weighed. The soil was transferred to a microscope slide with 2 -sided adhesive tape, and the number of particles and longest diameter were determined by visual observation under a dissecting microscope with an ocular micrometer. Calculations were done for both spherical and cuboidal particle shapes. In the second method, the total mass of the sample was divided by the number of particles to find the average mass per particle. This mass was then divided by $2.65 \mathrm{~g} \cdot \mathrm{cm}^{-3}$, the density of quartz, to determine an average particle volume. The surface of a particle was again calculated by assuming the particle was either a simple cube or a sphere. The averaged area was multiplied by the total number of particles in the sample and divided by the total mass of the sample to arrive at average surface area per gram of soil.

\section{Root and Rhizosheath Measurements}

Using a dissecting microscope for observation, we measured rhizosheath diameters with a micrometer for 5 samples from each of 3 grass species with the largest rhizosheaths (A. hymenoides, C. longifolia, and H. comata). The soil particles of the rhizosheath were carefully removed, and the root diameters (excluding root hairs) were also measured with a micrometer.

\section{Enumeration of Bacteria}

SCANNING ELECTRON MICROSCOPY.-Roots and rhizosheaths of the 4 different species of grasses collected from the sand dune sites were prepared for observation with SEM. Portions of roots with rhizosheaths were preserved in $70 \%$ ethanol and dehydrated in an ethanol series. Liquid carbon dioxide was substituted for ethanol, and in a critical point dryer (E3000 series II, Polaron Equipment Ltd., Watford Hertfordshire, U.K.) the temperature and pressure were increased to exceed $31{ }^{\circ} \mathrm{C}$ and $7.39 \mathrm{MPa}$ (critical point of carbon dioxide), respectively, to prevent damage by dehydration at ambient temperature and pressure.
The specimens were then coated with gold in a sputter coater (Effacoater 18930, E. F. Fullam Co, Clifton Park, NY) and examined using a scanning electron microscope $(5600 \mathrm{LV}$, JEOL USA, Peabody, MA) to observe rhizosheath structure and to quantify numbers of bacteria found within the rhizosheath complexes. We compared rhizosheaths of different grass species; the overall number of bacteria found; and the size, shape, and location of bacteria within the rhizosheath (on sand grains, on root hairs, or other). Bacteria counts from bulk soil collected from areas without observable plant roots were also measured by counting cells on soil particles on scanning electron micrographs. These counts were compared to counts from the rhizosheath samples. Bacterial numbers were quantified following the procedure outlined in Barnes et al. (2005). We recognize that SEM provides images of only surface structures but is valuable as it can provide images of microorganisms that cannot be cultured on standard media.

BACTERIAL CULTURE.-One gram of bulk soil or rhizosheath (including root) from a grass was vortexed at high speed for one minute in $10 \mathrm{~mL}$ of autoclaved tap water, diluted in autoclaved water, and plated onto R2A agar (Reasoner and Geldreich 1985) containing $40 \mathrm{mg}$. $\mathrm{mL}^{-1}$ cycloheximide to inhibit fungal growth. Plates were incubated at $25^{\circ} \mathrm{C}$ for 4 days.

\section{Acetylene Reduction to Ethylene}

The nitrogenase enzyme reduces acetylene to ethylene (Turner and Gibson 1980). Therefore, we evaluated the nitrogen fixation potential of the rhizosheath complex by assaying for this activity. We incubated rhizosheath samples in an atmosphere of nitrogen and 10\% acetylene and detected the percentage of acetylene that was converted to ethylene as an assay for potential nitrogenase activity. In this assay the rhizosheath and root material could not be easily separated, so $4.0 \mathrm{~g}$ of material containing both root tissue and rhizosheath were sealed in vials along with $600 \mu \mathrm{L}$ of sterile deionized water. Since Boddey (1987) indicated that nitrogenase activity associated with grasses is sensitive to $\mathrm{O}_{2}$, the vials were evacuated and filled with $\mathrm{N}_{2}$ gas at ambient pressure 3 times to completely remove $\mathrm{O}_{2}$. After the final purge and refill, 0.10 volume of acetylene was added to the vial to provide root material with a $90 \%$ $\mathrm{N}_{2}: 10 \%$ acetylene atmosphere, which is sufficient to achieve maximum reduction in grass 
species (Boddey 1987). Ethylene production undergoes an unexplained lag period (Boddey 1987), so samples were incubated at room temperature for 8 days. Two additional vials containing only $\mathrm{N}_{2}$ and acetylene were also incubated during this time to act as controls.

After the incubation period a $100-\mu \mathrm{L}$ sample of gas from each vial was injected into a GS-Q column (J\&W Scientific, Folsom, CA) in a gas chromatograph (Agilent 6890N, Agilent Technologies, Inc., Santa Clara, CA) equipped with a flame ionization detector (FID). In this column any ethylene is cleanly separated from acetylene and the relative amounts of the 2 gases can be determined from the output of the FID detector.

\section{Extraction of Microbial DNA and Amplification of nif $\mathrm{H}$}

The presence of the genes for dinitrogenase reductase $(n i f \mathrm{H})$ in bacteria associated with rhizosheaths was tested by extraction of microbial DNA and PCR amplification of nif $\mathrm{H}$. Genomic DNA was extracted from $4.0 \mathrm{~g}$ of soil from rhizosheaths (grass roots and adherent soil particles) of C. longifolia, P. smithii, A. hymenoides, and H. comata, as well as from 2 samples of bulk soil. DNA was extracted using the methods of Zhou et al. (1996), except that the incubations of soil with the detergent/proteinase $\mathrm{K}$ extraction buffer were 30 minutes instead of 2 hours. Crude DNA was then further purified with a $0.6-\mathrm{mL}$ spin-column containing Sepharose 4-B, followed by a spin-column containing polyvinyl polypyrrolidone.

We amplified microbial nif $\mathrm{H}$ genes to facilitate nif $\mathrm{H}$ cloning and sequencing. Polymerase chain reaction (PCR) was performed with $1-5$ ng of target DNA; 50 pmoles of each primer; dATP, dCTP, dGTP, and dTTP at $0.2 \mathrm{mM}$ each; and $0.3 \mathrm{U}$ Taq DNA polymerase (Eppendorf Inc., Hamburg, Germany) in a reaction buffer with $50 \mathrm{mM} \mathrm{KCl}, 10 \mathrm{mM}$ Tris-Cl (pH 8.3), 0.2 $\mathrm{mg} \cdot \mathrm{mL}^{-1} \mathrm{BSA}$, and $2.0-2.5 \mathrm{mM}$ magnesium acetate, in a total volume of $25 \mu \mathrm{L}$. PCR reactions were performed in a Minicycler (MJ Research, Inc., Beverly, MA) or in a GeneAmp 9600 (Perkin-Elmer, Norwalk, CT) thermal cycler. A set of primers, nifH-gl-f (5'GGTTGTGACCCGAAAGCTGA3') and nifH-g1-r (5'GCGTACATGGCCATCATCTC3'), was used (Buergmann et al. 2004) for PCR. After initial denaturation at $94{ }^{\circ} \mathrm{C}$ for 4 minutes, 50 cycles of $94{ }^{\circ} \mathrm{C}$ (denaturation) for 25 seconds, $55^{\circ} \mathrm{C}$ (annealing temperature) for 30 seconds, and 72 ${ }^{\circ} \mathrm{C}$ (extension) for 40 seconds were performed before a final incubation at $72{ }^{\circ} \mathrm{C}$ for 10 minutes.

\section{Cloning and Sequence Analysis}

After extraction of microbial DNA and amplification of bacterial nif $\mathrm{H}$ genes, nif $\mathrm{H}$ PCR products were cloned into plasmid vectors so that the nif $\mathrm{H}$ PCR products from different bacterial species could be separated from each other and sequenced. Microbial nif H PCR products were purified and cloned into a plasmid vector to facilitate DNA sequencing. PCR products (350 bp) amplified from DNA of bulk soil and rhizosheaths of A. hymenoides were isolated using agarose gel electrophoresis. The PCR products were extracted from excised gel slices using a Qiagen Qiex II kit (Qiagen, Inc., Valencia, CA) and the products were cloned into the pCR2.1 plasmid vector by using the TOPO-TA cloning kit and then transformed into Escherichia coli strain TOP-10 as directed by the manufacturer (Invitrogen, Inc., Carlsbad, CA). Transformed E. coli cells were plated out on McConkey agar with $0.1 \mathrm{mg} \cdot \mathrm{mL}^{-1}$ ampicillin so that cells transformed with the pCR2.1 plasmid vector could be selected by disruption of the plasmid $\beta$-galactosidase gene. Individual clones of E. coli were grown overnight at 37 ${ }^{\circ} \mathrm{C}$ in $3.0 \mathrm{~mL} \mathrm{LB}$ medium with $0.1 \mathrm{mg} \cdot \mathrm{mL}^{-1}$ ampicillin and plasmid DNA harvested with a commercial miniprep kit (Qiagen, Inc., Valencia, CA). The cloned PCR products were sequenced using the M13-20 primer and the Big Dye version 3.1 kit (ABI, Inc., Foster City, CA). Sequencing reactions were analyzed on an Applied Biosystems ABI Prism 310 Genetic Analyzer at the Center for Conservation of Biological Resources at Black Hills State University, Spearfish, SD. Sequences were edited and aligned using the CLUSTAL W program at the University of California San Diego supercomputing center (http://workbench.sdsc .edu/). NifH sequences from soil and rhizosheaths were analyzed using the BLAST program (Altschul et al. 1990) at NCBI (http:// www.ncbi.nlm.nih.gov/BLAST/).

\section{Statistical Analyses}

Root and rhizosheath comparisons were analyzed using one-way ANOVA. Root diameters were compared as well as rhizosheath diameters less root diameters. Bacterial enumeration was evaluated using two-way ANOVA 


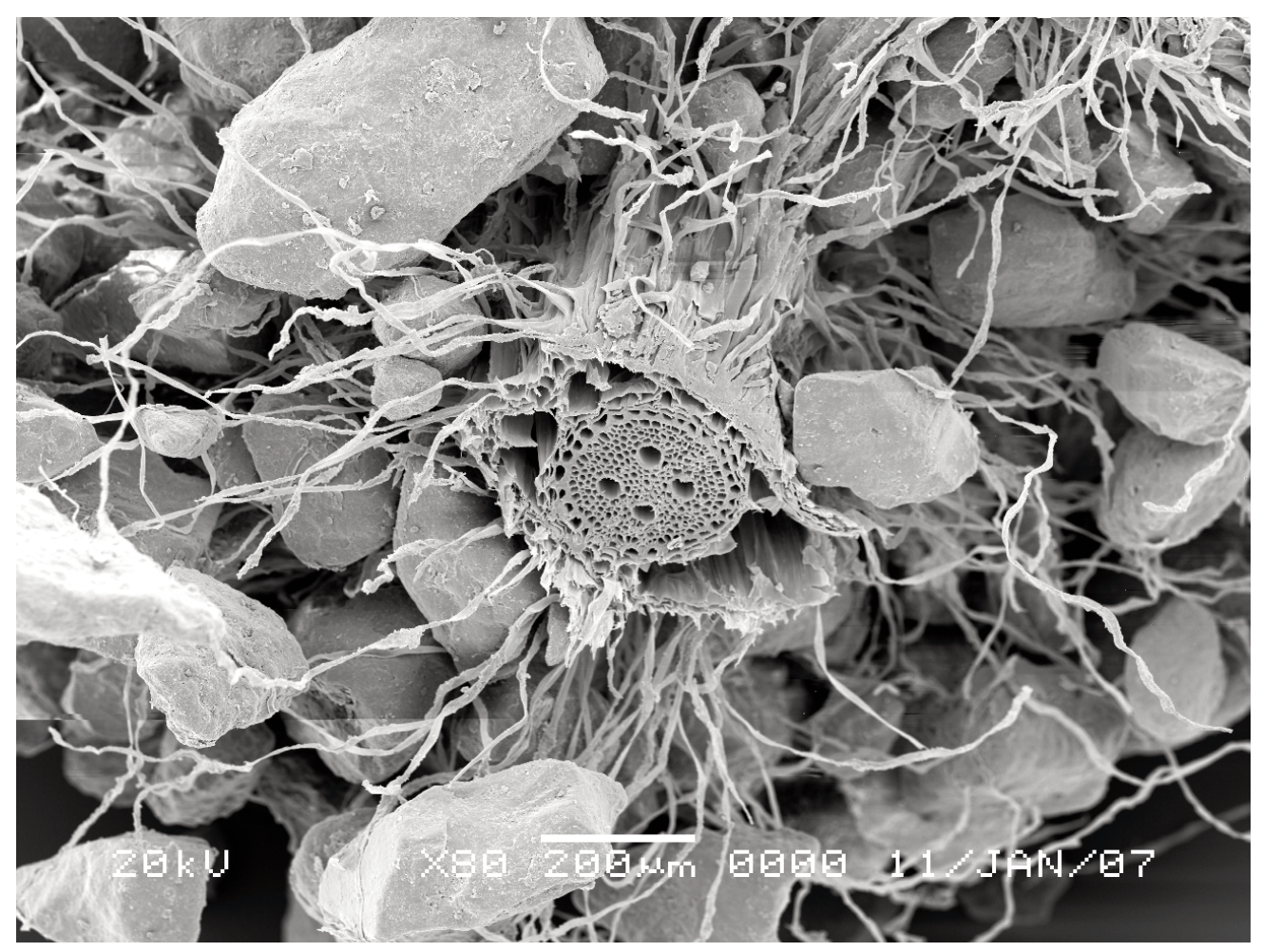

Fig. 1. Pascopyrum smithii: Scanning electron micrograph of root cross section and surrounding rhizosheath with attached soil particles.

to compare counts obtained for cultured bacteria (number $\cdot \mathrm{mm}^{-2}$ ), and counts obtained using SEM observations (number $\cdot \mathrm{mm}^{-2}$ ), from both rhizosheaths and bulk soil samples from interspaces. Tukey-Kramer post hoc tests were completed after the ANOVA. Acetylene reduction was analyzed using natural logtransformed data in a one-way ANOVA for comparisons between each of the grass species tested and the control vials.

\section{RESULTS}

Soil Characteristics and Root Diameters

Bulk soils from dune tops from the 2 transects in the study have an average $\mathrm{pH}$ of 7.9 and 8.0 , repectively, $1.3 \%$ and $1.2 \%$ organic matter, 3.3 and $1.7 \mathrm{ppm} \mathrm{NO}_{3}, 3$ and $4 \mathrm{ppm} \mathrm{P}$, and 140 and $123 \mathrm{ppm} \mathrm{K}$. One gram of dune topsoil had an average surface area of $1.9 \times 10^{4} \mathrm{~mm}^{2}$.

A comparison of bare-root diameters of the 3 plant species showed no significant differences among the root diameters, but rhizo- sheath diameters less the root diameters were significantly larger (ANOVA: $F_{5,24}=8.4, P=$ $0.0001)$. Rhizosheath diameters in A. hymenoides $\left(\bar{x}=1.51 \mathrm{~mm}, s_{\bar{x}}=0.16\right)$ were significantly larger than they were in H. comata $(\bar{x}$ $\left.=0.69 \mathrm{~mm}, s_{\bar{x}}=0.06\right)$ and C. longifolia $(\bar{x}=$ $\left.0.80 \mathrm{~mm}, s_{\bar{x}}=0.13\right)$; the latter two were not significantly different $(P>0.05)$.

\section{Bacterial Enumeration}

Enumeration of bacteria on rhizosheaths (example in Fig. 1) of the 4 grass species observed with SEM showed a range of bacterial density. The species with the most bacteria was $C$. longifolia with 529.1 bacteria $\cdot \mathrm{mm}^{-2}$ $\left(s_{\bar{x}}=135.1\right)$, while soil from interspaces between plants averaged only 45.9 bacteria $\cdot \mathrm{mm}^{-2}$ $\left(s_{\bar{x}}=7.3\right)$. Numbers of culturable bacteria from rhizosheaths, as estimated by bacterial colonies recovered on R2A media, were about 10-fold higher in the rhizosheaths of grasses than in bulk soil. The highest number of culturable bacteria, $9.9 \times 10^{7} \mathrm{CFU} \cdot \mathrm{g}^{-1}$ or $5178 \mathrm{CFU} \cdot$ $\mathrm{mm}^{-2}\left(s_{\bar{x}}=1583\right)$ was found in rhizosheaths 
TABLE 1. Percent frequency of bacterial morphotypes, as visualized by SEM, observed in rhizosheaths of 4 grass species and in bulk soil $\geq 1 \mathrm{~m}$ from any plants.

\begin{tabular}{lcccc}
\hline Grass species & Samples $(n)$ & Bacillus $(\%)$ & Coccus $(\%)$ & Actinomycete $(\%)$ \\
\hline Achnatherum hymenoides & 11 & 49 & 23 & 27 \\
Calamovilfa longifolia & 22 & 95 & 2 & 2 \\
Hesperostipa comata & 14 & 70 & 26 & 5 \\
Pascopyrum smithii & 22 & 35 & 59 & 6 \\
Soil & 38 & 16 & 84 & 0 \\
\hline
\end{tabular}

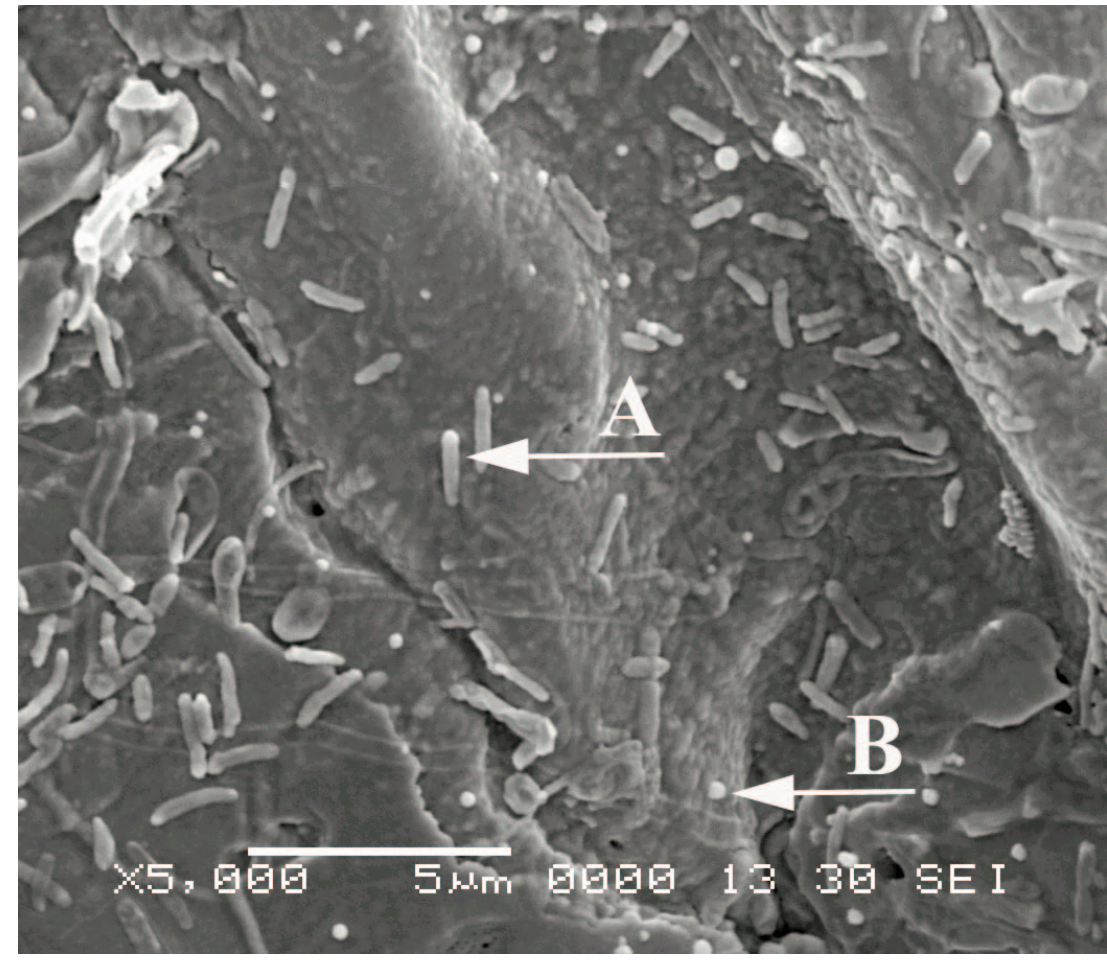

Fig. 2. Calamovilfa longifolia: Scanning electron micrograph of rhizosheath of showing (A) rod- and (B) coccus-shaped bacteria.

of C. longifolia, while bulk soil contained 0.3 $\times 10^{7} \mathrm{CFU} \cdot \mathrm{g}^{-1}$ or $171 \mathrm{CFU} \mathrm{mm}{ }^{-2}\left(s_{\bar{x}}=\right.$ $66.8)$.

A two-way ANOVA showed that cultured bacterial cell numbers were significantly larger than numbers observed using $\operatorname{SEM}\left(F_{1,1119}=\right.$ $117, P<<0.0001)$, and that bacterial abundance varied by grass species and bulk soil $\left(F_{3,4119}=16.3, P<<0.0001\right)$. Tukey-Kramer post hoc tests showed that all 4 grass species had significantly more bacteria than the bulk soil. In addition, $C$. longifolia rhizosheaths had more bacteria than A. hymenoides, H. comata, or $P$. smithii, and the latter 3 grasses were similar in bacterial numbers. We believe that a significant interaction between grass species and observational type $(F=11.2, P<<$ $0.0001)$ was observed because SEM grossly underestimated bacterial abundance on rhizosheaths, causing an inability to distinguish amongst the abundance of bacteria on rhizosheaths of various species of grasses.

Percentages of bacterial morphotypes observed by SEM varied among grass species (Table 1). Most species of grass had predominantly bacillus-type bacteria (Fig. 2), with the exception of $P$. smithii and bulk soil, which had higher percentages of coccus-type bacteria (Fig. 2). Actinomycetes (Fig. 3) were uncommon except in A. hymenoides rhizosheaths. 


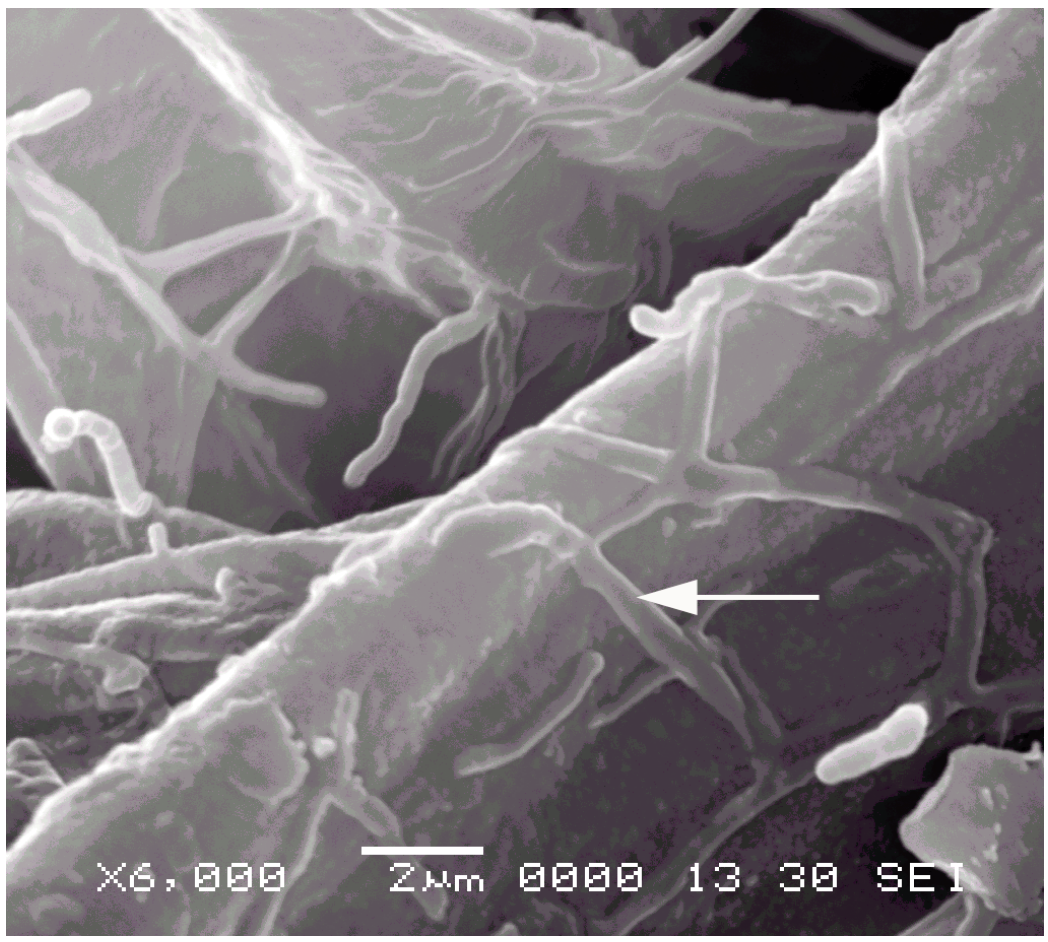

Fig. 3. Pascopyrum smithii: Scanning electron micrograph of actinomycetous bacteria (arrow) on the rhizosheath.

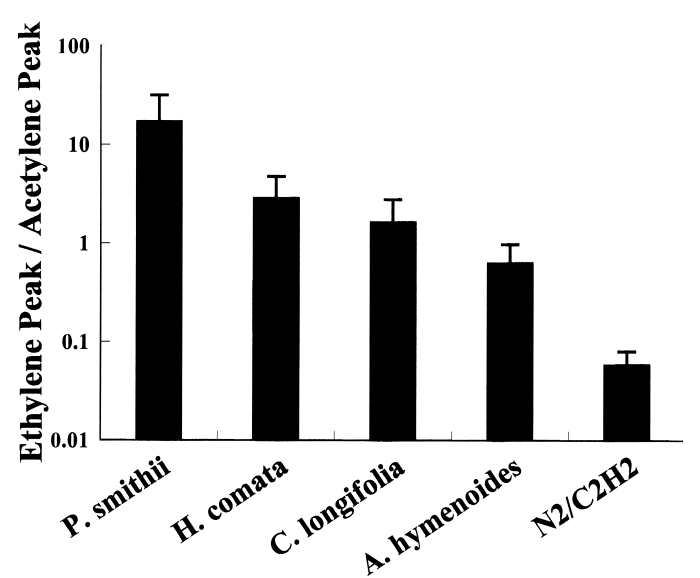

Fig. 4. Ethylene peaks / acetylene peaks for 4 samples of 4 grass species and controls (note $\log$ scale of $y$-axis). P. smithii = Pascopyrum smithii, $\mathrm{H}$. comata $=$ Hesperostipa comata, C. longifolia = Calamovilfa longifolia, A. hymenoides = Achnatherum hymenoides, $\mathrm{N} 2 / \mathrm{C} 2 \mathrm{H} 2=$ control vials with $90 \% \mathrm{~N}_{2}$ and $10 \% \mathrm{C}_{2} \mathrm{H}_{2}$.

\section{Acetylene Reduction to Ethylene}

The percent of acetylene converted to ethylene for samples from rhizosheaths of a particular grass species varied up to 3 orders of magnitude (Fig. 4), but due to large variance, differences in conversion among the grass rhizosheaths and controls were not significant (ln transformed, $F_{5,16}=1.5, P=0.25$ ). Individual sample values varied over 3 orders of magnitude, and the variances of these distributions were large. An additional control experiment was done where soil from a site with no plants growing within $1 \mathrm{~m}$ was also tested for acetylene reduction. After 24 hours the ethylene peak from the soil-only sample was $0.006 \%$ for the acetylene peak, and after 12 days the ethylene peak was $5.8 \%$ of the acetylene peak. Given these results, it was highly likely that all samples except one P. smithii sample $(0.08 \%)$ and one A. hymenoides sample $(0.09 \%)$ reduced acetylene to ethylene (Fig. 4). Interestingly, 2 other P. smithii samples also gave the largest values for acetylene-to-ethylene conversion.

\section{PCR and Analysis of nif H Genes}

Bulk soil samples yielded about $50 \mathrm{ng}$ DNA per gram soil, while rhizosheath samples yielded about $500 \mathrm{ng}$ of combined plant and microbial DNA per gram soil. Using universal bacterial $16 \mathrm{~S}$ rDNA primers as described by 
Barnes et al. (2005), we successfully amplified fragments of $16 \mathrm{~S}$ rRNA genes from $1.0 \mu \mathrm{L}$ of undiluted purified DNA samples from bulk soil and rhizosheaths. Our success indicated that PCR inhibitors had been largely removed from the samples.

PCR of bulk soil with primers nif H-g1-f and nif $\mathrm{H}-\mathrm{g} 1-\mathrm{r}$ produced a small amount of a 350 base-pair (bp) product only. PCR of rhizosheaths of C. longifolia, A. hymenoides, and $P$. smithii with the same primers yielded a mixture of PCR products of different sizes, including the expected $350 \mathrm{bp}$ nif $\mathrm{H}$ product, but only A. hymenoides yielded enough 350 bp PCR product for cloning. No PCR products were obtained from $H$. comata rhizosheaths. Gel-purified 350 bp PCR products from bulk soil and A. hymenoides rhizosheaths were cloned into the pCR2.1 plasmid vector and the nif $\mathrm{H}$ inserts of plasmids were sequenced. A total of 19 separate nifH clones from bulk soil were sequenced. All 19 soil nif $\mathrm{H}$ sequences were identical (Sequence 1). Among nifH sequences from cultured bacteria in GenBank, Sequence 1 (GenBank accession number EF158037) was most similar to nif $\mathrm{H}$ from Alcaligenes latus (gi|71040569|dbj| AB188122.1|) (94.3\% identity over 230 bp) and Ideonella sp. Long 7 (gi|33286718|gb| AY231580.1|) (93.0\% over 324 bp). For DNA from A. hymenoides rhizosheaths, a total of 16 clones with nif $\mathrm{H}$ sequences were obtained: 15 appeared identical to Sequence 1, while a second, Sequence 2, (GenBank accession number EF158038) was most similar (when compared with cultured isolates in GenBank) to nif $\mathrm{H}$ from Mesorhizobium loti MAFF303099 (gi| 47118328|dbj| BA000012.4|) (96.5\% identity over 315 bp).

\section{Discussion}

In an attempt to better understand the occurrence of several species of grasses in relatively inhospitable environments of low-moisture and low-nutrient sand dunes, we hypothesized that plant occurrence may have been mediated by nitrogen-fixing bacteria associated with moisture-retaining mucilagenous rhizosheaths. We found strong support for this hypothesis, as the lowest numbers of bacteria found by both methods (SEM and culturing) were in the bulk soil. Furthermore, Alcaligenes latus (Malik et al. 1981) and Mesorhizobium loti (Kaneko et al. 2000) isolated from rhizosheaths are capable of nitrogen fixation.

Higher bacterial numbers in rhizosheaths are probably due to bacteria using root exudates as a source of carbon and to higher water potentials in these systems. The numbers of CFUs we observed in rhizosheaths were similar to those reported by Gochnauer et al. (1989) for maize. The number of cultured bacteria we determined from the soil $\left(3.3 \times 10^{6} \mathrm{CFU}\right.$. $\left.\mathrm{g}^{-1}\right)$ was similar to the averaged values reported by Kuske et al. $\left(2002 ; 3.8 \times 10^{6} \mathrm{CFU}\right.$ $\left.\cdot \mathrm{g}^{-1}\right)$ for an arid (21.4 cm annual precipitation) grassland system. Achnatherum hymenoides, the sole grass species included in both our study and in Kuske et al. (2002), had >10 times more CFUs per gram in the rhizosheaths we studied than it had in the rhizosheaths studied by Kuske et al. $\left(2002 ; 44 \times 10^{6}\right.$ vs. $\left.3.5 \times 10^{6}\right)$. Kuske et al. (2002) collected specimens from drier habitats with less organic matter $(0.28 \%)$ and collected soil only via cores near plants. In our study, entire plants were excavated and bacteria were cultured directly from the root/rhizosheath complex. One could conclude that higher bacterial concentrations are present in the root/ rhizosheath complex than are present in the surrounding soil.

We observed fewer bacteria per unit surface area by SEM than by culturing. Previous reports (Barnes et al. 2005) comparing SEM observations with culture of bacteria have shown greater numbers of bacteria observed with SEM than were observed in culture. In this study the greater number of bacteria determined by culturing may be due to our inability to observe the inner surfaces of the intact rhizosheath with SEM. Only exposed surfaces of sand grains, root hairs, or root surfaces were observed. One can assume that concentrations of bacteria are higher in the internal portions of the rhizosheath or that many bacteria may be obscured by mucilage or present in biofilms. Bacteria in rhizosheath specimens were probably at least partially obscured due to an obvious mucilaginous coating present on the rhizosheaths. Support for the protective nature of the root/rhizosheath complex comes from Pohlman and McColl (1982) who noted that even after surface sterilization in $1 \%$ sodium hypochloride for 5 minutes, roots were still capable of acetylene reduction. It seems likely that some of the bacteria contained within the rhizosheath are protected from 
surface sterilization or that some bacteria are endophytic.

Acetylene reduction analysis indicates that nitrogen-fixing bacteria are associated with the rhizosheaths of several species of grasses we examined. We also observed that rhizosheaths from $P$. smithii produced more ethylene than those from $C$. longifolia. Some bacteria observed by SEM or by culturing are probably not capable of nitrogen fixation. The extreme sample-to-sample variation limits the utility of statistical comparisons among species. This high sample variation is not a problem unique to this study. Knowles and O'Toole (1975) indicated a large variation of acetylene reduction associated in replicate soil core assays. Whiting et al. (1986) reported a seasonal variation in acetylene reduction and noted that reduction is correlated with $\mathrm{CO}_{2}$ and photosynthesis levels. Pohlman and McColl (1982) showed that higher rates of acetylene reduction are associated with moisture levels close to saturation. Weaver and Danso (1994) have noted that in grasses, the nitrogen-fixation system inevitably changes due to changes in gas concentrations with collection, changes in the microbial community, and changes in the production of ethylene that may occur independently of acetylene reduction.

We successfully amplified nif $\mathrm{H}$ gene sequences from both bulk soil and from rhizosheaths of A. hymenoides by using the nifHgl-f and nifH-gl-r primers designed to amplify a fragment of nif $\mathrm{H}$ from the $\gamma$-subdivision of Proteobacteria. In both bulk soil and rhizosheaths of A. hymenoides, the community of nitrogen-fixing bacteria appears to be dominated by a single species, possibly belonging to a species close to Alcaligenes latus ( $\beta$-subdivision of Proteobacteria). Another species, possibly Mesorhizobium loti $(\alpha$-subdivision of Proteobacteria), was detected in rhizosheaths of A. hymenoides. We noted that PCR did not yield nif $\mathrm{H}$ products from $H$. comata rhizosheaths. This may be due to inhibitors present in soil and plant materials such as phenolic compounds, which prohibit amplification of nif $\mathrm{H}$ genes, or may indicate that there are too few nitrogen-fixing bacteria present to be detectable by ordinary methods. Despite the successful PCR amplification of $16 \mathrm{~S}$ genes from rhizosheath DNA samples, the samples had spectrophotometric absorbance ratios $(260 \mathrm{~nm} / 280 \mathrm{~nm})$ of 1.44 to 1.85 , indicating that some contaminants may still have been present.

This study enumerates the number of bacteria present on rhizosheaths of grasses growing in dry sandy areas of the north central Great Plains by SEM observation and bacterial culturing techniques. We found that there were more bacteria in the root/rhizosheath complex than in bulk soil. Also demonstrated is the ability of some of the microorganisms to reduce acetylene to ethylene, indicating their potential to fix nitrogen in the rhizosheath. $\mathrm{NifH}$ genes have been isolated from the bacteria, indicating the ability of the organisms to fix nitrogen.

\section{ACKNOWLEDGMENTS}

The authors dedicate this paper to the memory of Linda Zierer - an undergraduate student, employee, and research partner. We greatly miss her enthusiasm and curiosity about living things. This project was funded through a Black Hills State University Faculty Research Grant to D. Bergmann and M. Gabel. We thank C. Ferrell and T. Berger at the BHSU Center for the Conservation of Biological Resources for their valuable help with DNA sequencing. The project was also supported in part by Grant Number 2 P20 RR016479 from the National Center for Research Resources (NCRR), a component of the National Institutes of Health (NIH). Its contents are solely the responsibility of the authors and do not necessarily represent the official views of NCRR or NIH. The generous permission from the landowner, Edwin Hunsucker, for access to the site is greatly appreciated. We appreciate the comments of A. Gabel, D. Siemens, S. St. Clair, an anonymous reviewer, and the editorial staff of Western North American Naturalist on this manuscript. The facilities of the BHSU Scanning Electron Microscope Facility and the BHSU Herbarium and Chemistry Research Laboratories were used in the preparation of this report.

\section{Literature Cited}

Altschul, S.F., W. Gish, W. Miller, E.W. Myers, and D.J. Lipman. 1990. Basic local alignment search tool. Journal of Molecular Biology 215:403-410.

Andrews, M., E.K. James, S.P. Cummings, A.A. Zavalin, L.V. Vinogradova, And B.A. McKenzie. 2003. Use of nitrogen fixing bacteria inoculants as a substitute for nitrogen fertiliser for dryland graminaceous crops: 
progress made, mechanisms of action and future potential. Symbiosis 35:209-229.

Barnes, M.E., D.J. Bergmann, H. Stephenson, M. Gabel, AND R.J. CoRdEs. 2005. Bacterial numbers from landlocked fall chinook salmon eyed eggs subjected to various formalin treatments during vertical-flow incubation as determined by scanning electron microscopy and bacteriological culture methods. North American Journal of Aquaculture 67:23-33.

BoDdey, R.M. 1987. Methods for quantification of nitrogen fixation associated with the Gramineae. Critical Reviews in Plant Sciences 6:209-266.

BuCKLEY, R. 1982. Sand rhizosheath of an arid zone grass. Plant and Soil 66:417-421.

Buergmann, H., F. Widmer, W. Von Siegler, and J. ZEYER. 2004. New molecular tools for analysis of free-living diazotrophs in soil. Applied Environmental Microbiology 70:240-247.

Campbell, C.S. 1985. The subfamilies and tribes of Gramineae (Poaceae) in the southeastern United States. Journal of the Arnold Arboretum 66:123-199.

CAPONE, D.G. 1993. Determination of nitrogenase activity in aquatic samples using the acetylene reduction procedure. Pages 621-631 in P.F. Kemp, B.F. Sherr, E.B. Sherr, and J.J. Cole, editors, Handbook of methods in aquatic microbial ecology. Lewis Press, Boca Raton, FL

Gochnauer, M.B., M.E. McCully, and H. Labbé. 1989 Different populations of bacteria associated with sheathed and bare regions of roots of field-grown maize. Plant and Soil 114:107-120.

Hawkes, C.V., K.M. DeAngelis, and M.K. Firestone. 2007. Root interactions with soil microbial communities and processes. Pages 1-29 in Z.G. Cardon and J.L. Whitbeck, editors, The rhizosphere: an ecological perspective. Academic Press, New York.

Hopkins, A. 2000. Herbage production. Pages 90-110 in A. Hopkins, editor, Grass: its production and utilization. 3rd edition. Blackwell Science, Oxford, U.K.

Johnson, W.F. 1988. Soil survey of Harding County. United States Department of Agriculture, Soil Conservation Service, U.S. Government Printing Office 0-183-544:QL3.

Judd, W.S., C.S. Campbell, E.A. KellogG, and P.F. Stevens. 1999. Plant systematics: a phylogenetic approach. Sinauer, Sunderland, MA.

Kaneko, T., Y. Nakamura, S. Sato, E. Asamizu, T. Kato, S. Sasamoto, A. Watanabe, K. Idesawa, A. Ishikawa, K. KAWASHIMA, ET AL. 2000. Complete genome structure of the nitrogen-fixing symbiotic bacterium Mesorhizobium loti. DNA Research 7:331-338.

KNOwLES, R., AND P. O'ToOLE. 1975. Acetylene-reduction assay at ambient $\mathrm{pO}_{2}$ of field and forest soils: laboratory and field studies. Pages 285-294 in W.D.P. Stewart, editor, Nitrogen fixation by free-living microorganisms. Cambridge University Press, Cambridge, U.K.

Kuske, C.R., L.O. Ticknor, M.E. Miller, J.M. Dunbar, J.A. Davis, S.M. Barns, and J. Belnap. 2002. Comparison of soil bacterial communities in rhizospheres of three plant species and the interspaces in an arid grassland. Applied and Environmental Microbiology 68:1854-1863.

Madigan, M.T., And J.M. Martinko. 2006. Brock biology of microorganisms. 11th edition. Pearson Prentice Hall, Upper Saddle River, NJ.
Malik, K.A., C. Jung, D. Claus, and H.G. Schlegel. 1981. Nitrogen fixation by the hydrogen-oxidizing bacterium Alcaligenes latus. Archives of Microbiology 129:254-256.

Pohlman, A.A., AND J.G. McColL. 1982. Nitrogen fixation in the rhizosphere and rhizoplane of barley. Plant and Soil 69:341-352.

Price, S.R. 1911. The roots of some North African desert grasses. New Phytologist 10:328-340.

Reasoner, D.J., and E.E. Geldreich. 1985. A new medium for the enumeration and subculture of bacteria from potable water. Applied and Environmental Microbiology 49:1-7.

Schlesinger, W.H. 1991. Biogeochemistry: an analysis of global change. Academic Press, San Diego, CA.

South Dakota Office of Climatology. 2006. South Dakota climate and weather. South Dakota State University, Brookings, SD. Available from: http://climate.sdstate.edu/climate_site/climate.htm

Turner, G.L., AND A.H. GibSON. 1980. Measurement of nitrogen fixation by indirect means. Pages 111-138 in FJ. Bergersen, editor, Methods for evaluating biological nitrogen fixation. Wiley, New York.

van Diepeningen, A.D., O. De Vos, V.V. Zelenev, A.M. Semenov, AND A.H.C. VAN BRuggen. 2005. DGGE fragments oscillate with or counter to fluctuations in cultivable bacteria along wheat roots. Microbial Ecology 50:506-517.

WANG, S.Z., J.S. Chen, AND J.L. Johnson. 1988. The presence of five nifH-like sequences in Clostridium pasteurianum: sequence divergence and transcription properties. Nucleic Acids Research 16:439-454.

Ward, D.M., R. WEller, and M.M. Bateson. 1990. 16S rRNA sequences reveal numerous uncultured microorganisms in a natural community. Nature 345:63-65.

WEAVER, R.W., AND S.K. DANSO. 1994. Dinitrogen fixation. Pages 1019-1045 in R.W. Weaver, J.S. Angle, and P.S. Bottomley, editors, Methods of soil analysis. Part 2, Microbiological and biochemical properties. Soil Science Society of America, Madison, WI.

Whiting, G.J., E.L. Gandy, and D.C. Yoch. 1986. Tight coupling of root-associated nitrogen fixation and plant photosynthesis in the salt marsh grass Spartina alterniflora and carbon dioxide enhancement of nitrogenase activity. Applied and Environmental Microbiology 52:108-113.

Wullstein, L.H. 1980. Nitrogen fixation (acetylene reduction) associated with rhizosheaths of Indian ricegrass used in stabilization of the Slick Rock, Colorado tailings pile. Journal of Range Management 33:204206.

Wullstein, L.H., M.L. Bruening, and W.B. Bollen. 1979. Nitrogen fixation associated with rhizosheaths of certain perennial grasses. Physiologia Plantarum 46:1-4.

YounG, I.M. 1995. Variation in moisture contents between bulk soil and the rhizosheath of wheat (Triticum aestivum L. cv. Wembly). New Phytologist 130:125-139.

Zhou, Z., M.A. Bruns, And J.M. Tiedje. 1996. DNA recovery from soils of diverse composition. Applied and Environmental Microbiology 62:316-322.

Received 8 June 2007 Accepted 12 September 2008 